\title{
Vesicocutaneus fistula after cesarean section-a curious complication: Case report and review
}

\section{Sezeryan sonrası ilginç nadir bir komplikasyon vezikokutanöz fistül: Olgu sunumu ve derleme}

\author{
Burak Tatar1, Ebru Erdemoğlu², Sedat Soyupek ${ }^{3}$, Yakup Yalçın1, Evrim Erdemoğlu1 \\ 1Süleyman Demirel University Faculty of Medicine, Department of Gynecologic and Oncology, Isparta, Turkey \\ 2Isparta Maternity Hospital, Clinic of Obstetrics and Gynecology, Isparta, Turkey \\ 3 Süleyman Demirel University Faculty of Medicine, Department of Urology, Isparta, Turkey
}

\begin{abstract}
Vesicocutaneous fistulas are very rare pathologies in the urinary tract. We present the second case of a vesicocutaneus fistula after cesarean section, and discuss strategies for prevention, diagnosis, and treatment of this exceptional complication. A woman with a vesicocutaneous fistula after cesarean delivery was admitted and diagnostic tests including fluoroscopy, magnetic resonance imaging (MRI), and reconstructed MRI revealed the fistula tract and an urachal anomaly. The patient was treated through excision of the fistula tract. Laparotomy should be performed carefully, and the surgeon should be aware of the urachus. Inadvertent trauma to the urachus during laparotomy might cause serious unexpected complications. Possible etiologic factors for vesicocutaneous fistulae, prevention, and treatment methods are discussed.
\end{abstract}

Keywords: Cesarean delivery, vesicocutaneous fistula, urachus, diagnosis, treatment

$\ddot{\mathrm{O} z}$

Vezikokutanöz fistüller, idrar yollarında çok nadir olarak görülen patolojilerdir. Sezaryen sonrasında meydana gelen bir vezikokutanöz fistülün olgu sunumunu ilk defa paylaşmaktayız. Ayrıca bu sıradışı komplikasyonun önlenmesi, tanısı ve tedavisi için stratejiler tartışılmıştır. Sezaryen sonrası vezikokutanöz fistül ile kabul edilen hastaya tanı için floroskopi, manyetik rezonans (MR), rekonstrükte MR yapılmıştır ve urakal anomali saptanmışır. Hasta, fistül yolunun eksizyonu ile tedavi edilmiştir. Laparotomi dikkatle yapılmalıdır ve cerrah urakusun farkında olmalıdır. Laparotomi sırasında urakusun yanlışlıkla travmatize olması, ciddi ve beklenmeyen komplikasyonlara neden olabilir. Vezikokütanöz fistülün etiyolojisinde rol oynayabilen faktörler, bu durumun önlenmesi ve tedavi yöntemleri tartışlmıștır.

Anahtar Kelimeler: Sezaryen doğum, vezikokutanöz fistül, urakus, tanı, tedavi

PRECIS: We present the second reported case of vesicocutaneus fistula occurring after cesarean section, and discuss strategies for prevention, diagnosis, and treatment of this exceptional complication.

\section{Introduction}

The cesarean delivery rate has risen from 4.5 percent to 31.8 percent of all deliveries ${ }^{(1)}$. Lower urinary tract injuries are not infrequent and may occur during this procedure. If not intraoperatively detected and repaired, diagnosis will be delayed and a genitourinary fistula may be encountered later. There are case reports of vesico-vaginal, uretero-vaginal, vesico-uterine fistulas after cesarean section. There are also reported cases of uretero-vesico-cervical and vesico-peritoneal fistulas (2-4). Vesicocutaneous fistulas are very rare pathologies in the urinary tract. Trauma, neoplasia, inflammation, and iatrogenic injury are the most frequent causes. Anomalies of the urachus may predispose patients to injury and subsequent fistula formation during surgery due to the distorted anatomy. We present the second case of vesicocutaneus fistula, which occurred after cesarean section, and discuss strategies for prevention, diagnosis, and treatment of this exceptional complication.

\section{Case Report}

A gravida 2, para 2 woman aged 44 years with a history of two cesarean sections was referred because of recurrent urinary 
tract infection and urinary leakage through the abdomen. In her past medical history, she had Sjogren's syndrome and optic neuritis. In her past surgical history, she had a bladder injury in a caesarean section, which was repaired with a primary suture. One month later, she presented with a $10 \mathrm{~cm}$ subcutaneous hematoma at its largest dimension. The hematoma was drained surgically, and during the exploration, no source of bleeding was found. Four months later (in total, five months after the cesarean section), she was admitted to the hospital and referred for urinary leakage through the abdomen, about $5 \mathrm{~cm}$ below the level of umbilicus. The leakage was periodic and she had an episode of subcutaneous abscess, which was managed conservatively using antibiotics and non-steroidal anti-inflammatory drugs.

A fistula tract was observed in a retrograde fluoroscopic examination; however, the distal end of the fistulous tract was not clear (Figure 1). An ultrasound examination was also not helpful to clarify the lesion. Contrast-enhanced magnetic resonance (MR) urography (Figure 2) revealed a defect of $1.2 \mathrm{~cm}$ on the anterior wall of the bladder in the midline. Between this defect and subcutaneous fatty tissue, a fistula tract of $2 \mathrm{~cm}$ at its widest diameter was evident. In the subcutaneous fatty tissue, a

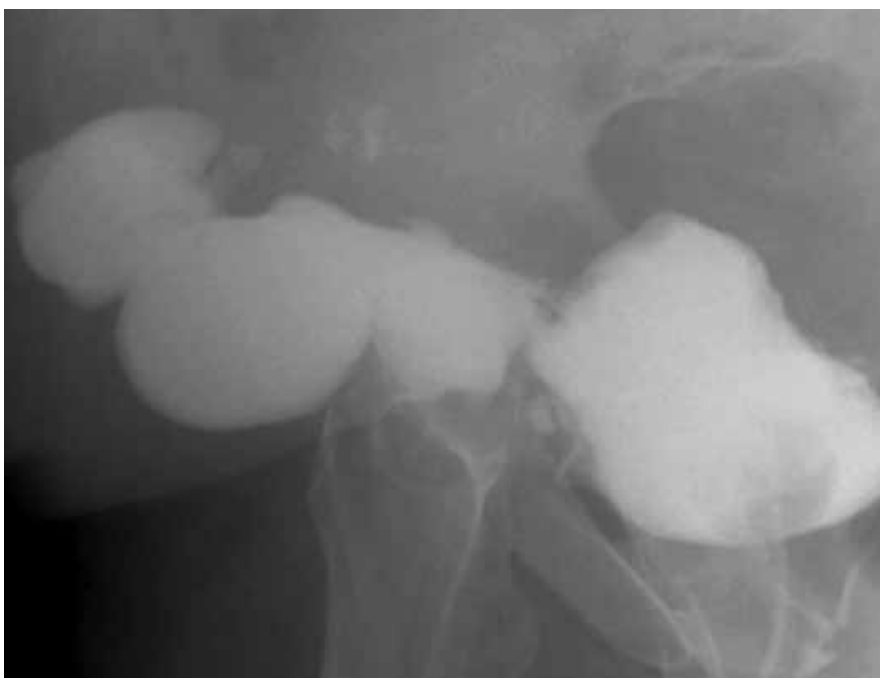

Figure 1. Fluoroscopic lateral view

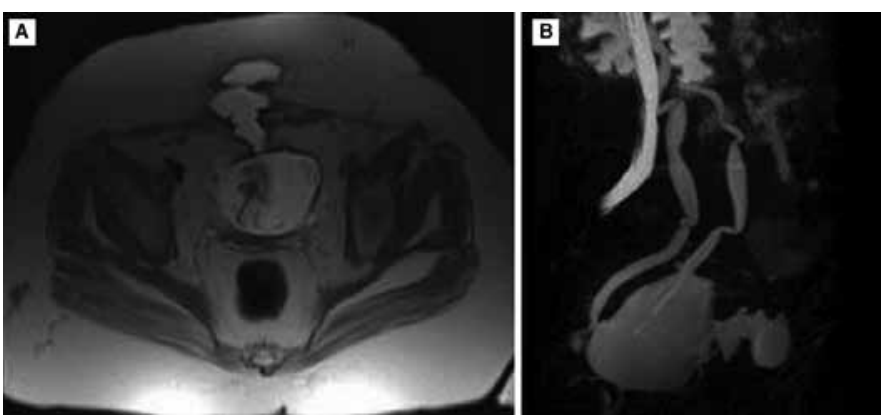

Figure 2. A: T2 Weighted image of the vesico-cutaneous fistula. B: Reconstructed lateral-oblique magnetic resonance image. Fistula tract is clearly seen
$6 \times 6.4 \times 3.7 \mathrm{~cm}$ collection was directly related with the fistula tract. There was inflammation and possible infection surrounding the collection due to the dense contrast enhancement.

The patient underwent a laparotomy with the plan for excision of the fistula tract and repairing the bladder defect. A suprapubic incision parallel to the Langer's lines of the skin was made with a 1.5-2 cm margin with the fistulous tract. The fistula tract was about $12 \mathrm{~cm}$ in length and $4 \mathrm{~cm}$ wide, and was totally excised with the involved skin (Figure 3,4). The defect on the dome of the bladder, which is apart from the trigon, was closed in 3 layers. The rectus fascia was closed with 1-0 Vicryl Subcuticular tissue was repaired with interrupted 2-0 Vicryl and the skin was repaired with 3-0 Prolene sutures. Her two-month follow-up after the surgery was unremarkable.

\section{Discussion}

Vesicocutaneus fistulas are rare. Their exact incidence is not known due to their rarity. Trauma, neoplasia, inflammation, and

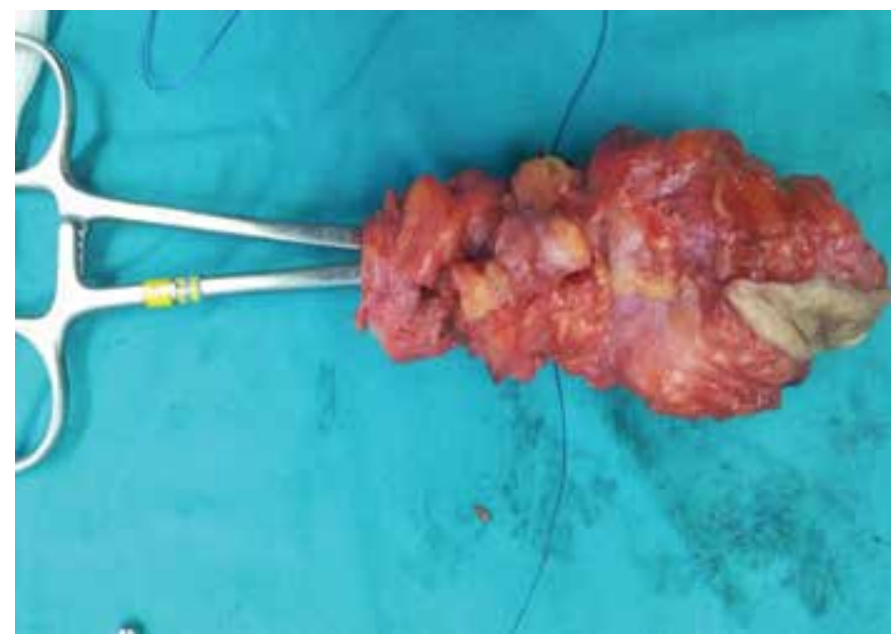

Figure 3. Fistula tract totally excised with the outer edge on the skin

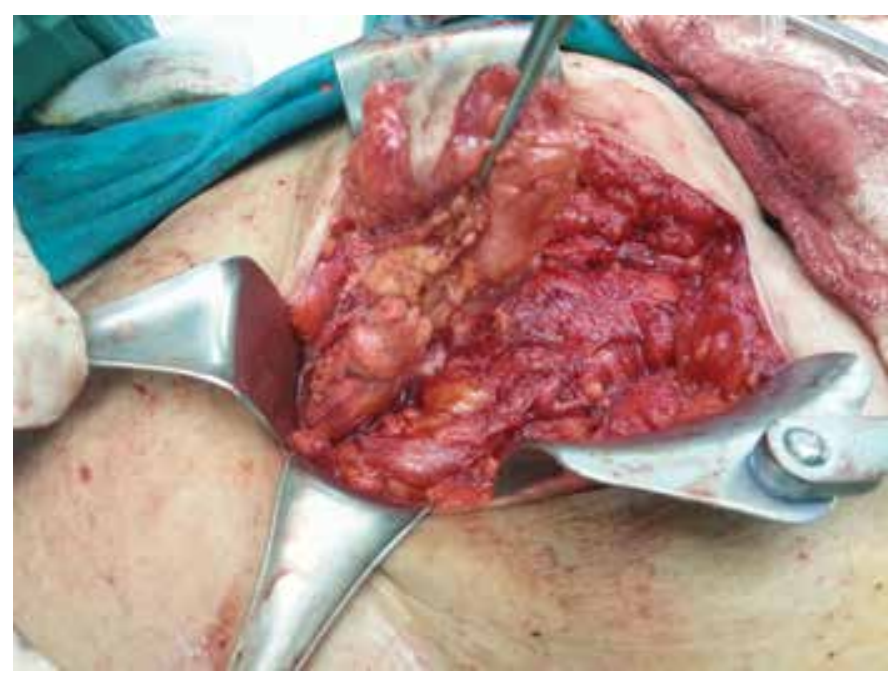

Figure 4. Excision of the fistula tract via laparotomy 
iatrogenic injury are the most frequent causes of these urinary fistulas $(1,5)$. Due to the rarity of vesicocutaneus fistulas, their risk factors are not clearly identified. Pelvic radiation, radical hysterectomies, pelvic fractures, hip arthroplasties, bladder calculus, and inguinoscrotal hernia operations are reported risk factors $(6)$. Actinomyces infections and factitious disorders have also been reported to cause vesicocutaneous fistula $(7,8)$. Unrecognized urachal anomalies may be a predisposing risk factor during surgical procedures. Cesarean delivery might be a risk factor due to the nature of the procedure, compared with vaginal delivery. There was an urachal anomaly, a possible urachal diverticula that was asymptomatic until the surgical intervention in our case. Urachal anomalies are very rare. Their true incidence is unknown, but is estimated to be between 0.015 to 0.13 in 1000 births according to a large case series $(6,7)$. They may be asymptomatic, especially when presenting as a urachal cyst or diverticulum. These anomalies may predispose a patient to injury during abdominal surgery, especially in cesarean section. Inadvertent injury to the urachus with a diverticulum may be complicated by vesicocutaneous fistula.

Radiographic imaging is the traditional method to identify a fistula. Fluoroscopy may identify the lesion, but it may not clarify it. Sonography was one of the imaging modalities used in the past, but due to its poor sensitivity, especially in identifying complexity, size, and multiplicity, it is rarely used now for identification of fistulae(8). Magnetic resonance imaging and computed tomography (CT) are currently the imaging modalities of choice for the initial evaluation of patients with suspected pelvic fistulae(9). MR seems to be one of the most sensitive methods to define the exact location and complexity of a fistula tract, with more than 90\% sensitivity and correlates well with surgical findings(10). Multi-detector CT is the choice for patients who are unable to tolerate fluoroscopy or MR imaging. As in our case, the best imaging modality was contrast-enhanced magnetic resonance (MR) imaging, which clearly identified the exact location of the lesion and its relation with the surrounding tissues.

There is one case report of vesicocutaneus fistula secondary to cesarean hysterectomy from Pakistan by Toufique and Merani(11). It was treated with conservative management and an indwelling bladder catheter was left for 3 weeks and parenteral antibiotics were given. The authors reported that the fistula tract closed spontaneously. A conservative approach may be tried in small fresh fistulas. We chose a curative surgical approach for a major fistula. The treatment approach depends on type of the fistula, symptoms, the time passed from injury, and the patient. For vesico-vaginal fistula, fistulectomy is the preferred management method. Delayed repair is the classic approach, but some articles advocated immediate repair because of better results(12-14). Conservative management is also described, but an option not chosen frequently ${ }^{(15)}$. When the case is a uretero-vaginal fistula, conservative management can be considered initially, especially if the patient is appropriate for ureteral stenting, otherwise surgery is the definitive treatment method(16). Vesicocutaneous fistulas are very rare, and to the best of our knowledge, there has been no report of a vesicocutaneus fistula occurring secondary to cesarean section and as a consequence, the optimal management strategy is unknown.

Although conservative management can be reasonable in asymptomatic patients with urachal remnants, fistulectomy with primary closure of the bladder is a logical approach, especially for symptomatic patients with recurrent infections as in our case(17). Laparotomy should be performed carefully, and the surgeon should be aware of patent urachus. Inadvertent trauma to the urachus during laparotomy might be a cause for serious unexpected complications.

\section{Ethics}

Informed Consent: A Consent form was filled out by all participants. Peer-review: Externally peer-reviewed.

\section{Authorship Contributions}

Surgical and Medical Practices: Sedat Soyupek, Evrim Erdemoğlu, Concept: Evrim Erdemoğlu, Sedat Soyupek, Design: Evrim Erdemoğlu, Burak Tatar, Ebru Erdemoğlu, Data Collection or Processing: Burak Tatar, Analysis or Interpretation: Burak Tatar, Ebru Erdemoğlu, Literature Search: Burak Tatar, Yakup Yalçn, Writing: Burak Tatar, Evrim Erdemoğlu, Ebru Erdemoğlu.

Conflict of Interest: No conflict of interest was declared by the authors.

Financial Disclosure: The authors declared that this study has received no financial support.

\section{References}

1. MacDorman MF, Menacker F, Declercq E. Cesarean birth in the United States: Epidemiology, trends, and outcomes. Clinics perinatol 2008;35:293-307.

2. Jozwik M, Jozwik M, Lotocki W. Vesicouterine fistula -an analysis of 24 cases from Poland. Int J Gynecol Obstet 1997;57:169-72.

3. El-Tabey NA, Ali-El-Dein B, Shaaban AA, El-Kappany HA, Mokhtar AA, El-Azab M, et al. Urological trauma after gynecological and obstetric surgeries. Scand J Urol Nephrol 2006;40:225-31.

4. Tsivian M Jr, Tsivian M, Sidi AA, Tsivian A. Uretero-vesico-cervical fistula following a caesarean section: A unique case report. Int Urogynecol J 2012;23:1639-41.

5. Betran AP, Merialdi M, Lauer JA, Bing-Shun W, Thomas J, Van Look P, et al. Rates of caesarean section: analysis of global, regional and national estimates. Paediatric Perinat Epidemiol 2007;21:98113.

6. Nix JT, Menville JG, Albert M, Wendt DL. Congenital patent urachus. J Urol 1958;79:264-73.

7. Blichert-Toft M, Nielsen OV. Congenital patient urachus and acquired variants. Diagnosis and treatment. Review of the literature and report of five cases. Acta Chir Scand 1971;137:807-14.

8. Adetiloye VA, Dare FO. Obstetric fistula: evaluation with ultrasonography. J Ultrasound Med. 2000;19:243-9. 
9. Narayanan P, Nobbenhuis M, Reynolds KM, Sahdev A, Reznek RH, Rockall AG. Fistulas in malignant gynecologic disease: etiology, imaging, and management. Radiographics 2009;29:1073-83.

10. Healy JC, Phillips RR, Reznek RH, Crawford RA, Armstrong P, Shepherd JH. The MR appearance of vaginal fistulas. AJR Am J Roentgenol 1996;167:1487-9.

11. Toufique H, Merani AJ. Vesicocutaneous fistula. J Park Med Assoc 2011;61:918-9.

12. Hadzi-Djokic J, Pejcic TP, Acimovic M. Vesico-vaginal fistula: Report of 220 cases. Int Urol Nephrol 2009;41:299-302.
13. Waaldijk K. The immediate management of fresh obstetric fistulas. Am J Obstet Gynecol 2004;191:795-9.

14. Shelbaia AM, Hashish NM. Limited experience in early management of genitourinary tract fistulas. Urology 2007;69:572-4.

15. Wild TT, Bradley CS, Erickson BA. Successful conservative management of a large iatrogenic vesicovaginal fistula after loop electrosurgical excision procedure. Am J Obstet Gynecol 2012;207:4-6.

16. Shaw J, Tunitsky-Bitton E, Barber MD, Jelovsek JE. Ureterovaginal fistula: a case series. Int Urogynecol J 2014;25:615-21.

17. Naiditch JA, Radhakrishnan J, Chin AC. Current diagnosis and management of urachal remnants. J Pediatr Surg 2013;48:2148-52. 